\title{
Assessing the Climate Impacts of Cookstove Projects: Issues in Emissions Accounting
}

\author{
Carrie M. Lee ${ }^{1, *}$, Chelsea Chandler ${ }^{1}$, Michael Lazarus ${ }^{1}$ and Francis X. Johnson ${ }^{2}$ \\ ${ }^{1}$ Stockholm Environment Institute, 1402 Third Ave., Suite 900, Seattle, WA 98115, USA; \\ E-Mail: carrie.lee@sei-us.org (C.M.L.) Tel.: +1 2065474000; Fax: +1 2063124720 \\ ${ }^{2}$ Stockholm Environment Institute, Kräftriket 2b, Stockholm, SE 106 91, Sweden \\ * Corresponding author
}

Submitted: 12 April 2013 | In revised form: 10 July 2013 | Accepted: 30 July 2013 |

Published: 17 September 2013

\begin{abstract}
An estimated 2.6 billion people rely on traditional biomass for home cooking and heating, so improving the efficiency of household cookstoves could provide significant environmental, social and economic benefits. Some researchers have estimated that potential greenhouse gas emission reductions could exceed 1 billion tons of carbon dioxide equivalent $\left(\mathrm{CO}_{2} \mathrm{e}\right)$ per year. Carbon finance offers a policy mechanism for realizing some of this potential and could also bring improved monitoring to cookstove projects. However, there are formidable methodological challenges in estimating emission reductions. This paper evaluates the quantification approaches to three key variables in calculating emission impacts: biomass fuel consumption, fraction of non-renewable biomass, and emission factors for fuel consumption. It draws on a literature review as well as on interviews with technical experts and market actors, and identifies lessons learned and knowledge gaps. Key research needs identified include incorporating accounting for uncertainty; development of additional default factors for biomass consumption for baseline stoves; refinement of monitoring approaches for cookstove use; broadened scope of emission factors used for cookstoves; accounting for non- $\mathrm{CO}_{2}$ gases and black carbon; and refinement of estimates and approaches to considering emissions from bioenergy use across methodologies.
\end{abstract}

Keywords: carbon market; carbon accounting; household energy 


\section{Introduction}

Globally around 2.6 billion people- $-40 \%$ of the world's population-still rely on traditional biomass (wood, crop residues, dung, etc.) to meet household cooking needs [1]. Nearly three-quarters of these biomass users are in developing Asia, one-quarter in Africa, and the rest in Latin America and the Middle East; in some countries, such as Ethiopia, the Democratic Republic of Congo, Tanzania, Uganda and Bangladesh, over $90 \%$ of the population relies on these traditional cooking fuels [1].

Indoor air pollution from the use of open fires and smoky stoves is a major health hazard, responsible for an estimated 2 million deaths per year, and now believed to exceed the combined health burdens of malaria, tuberculosis and HIV [2]. Fuelwood collection can also pose risks to personal safety and keeps women and children away from school or incomeproducing work, and it puts significant pressure on forests and scrubland. Moreover, traditional biomass burning produces greenhouse gases (GHGs) and black carbon, contributing to climate change.

$B_{y}$ reducing these risks and pressures, improved cookstoves can yield numerous health, economic and environmental benefits. Moreover, cookstove projects can provide employment opportunities, both making and selling new stoves, and can contribute to technology transfer $[3,4]$.

Cookstove projects to date have drawn on a wide range of public and private sources of finance. Major international sources have included the Global Environment Facility, carbon funds administered by the World Bank and the International Finance Corporation, and Climate Investment Funds. Most recently, the Global Alliance for Clean Cookstoves, a public-private partnership launched in 2010 and managed by the UN Foundation, has set a goal of bringing clean cookstoves and fuels to 100 million households by 2020 [5].

Still, attracting sufficient finance, especially for large-scale cookstove projects, has been difficult. This has led some to suggest a "new" potential solution to this "old" problem: monetizing the emission reduction benefits of improved cookstove projects to attract carbon-market finance (see, e.g., [6]). Several projects have already achieved this, through the Clean Development Mechanism (CDM) under the United Nations Framework Convention on Climate Change (UNFCCC) and other market mechanisms, but much more could be done.

The global technical potential for GHG emission reductions from improved cookstove projects has been estimated as 1 gigaton of carbon dioxide (1 Gt $\mathrm{CO}_{2}$ ) per year, with estimates of offsets generated ranging from $0.5-2 \mathrm{tCO}_{2}$ per year $[3,7]$. The low relative cost of abatement, combined with the strong co-benefits for rural livelihoods and the environment, has provided a strong rationale for targeting these project types [8]. The minimum break-even price for Certified Emission Reductions (CERs) under the CDM range from \$3-12 per CER depending on the reductions achieved per stove [7]. These estimates make such projects attractive when offset prices are expected to stay above $\$ 10$ per $\mathrm{tCO}_{2} \mathrm{e}$. Such price levels were achieved for voluntary Verified Emission Reductions (VERs) under the Gold Standard and Certified Emission Reductions (CERs) under the CDM for several years (2009-2011), before prices collapsed to about $\$ 1$ in late 2012 for CERs and $\sim \$ 5$ for high quality Gold Standard credits. Thus the viability of carbon-market finance for cookstove projects will depend on the viability of the markets themselves, which in turn is driven by demand for offset credits by emitters meeting mandatory and voluntary GHG emission reduction targets of varying ambition. If prices remain below the marginal cost of the projects themselves, finance sources other than the carbon market may be needed.

Another consideration is that although CDM projects are meant to serve dual objectives-both emission reductions and sustainable developmentserious questions have been raised about how well CDM projects actually deliver on their sustainable development objectives [9-16]. In part to address those concerns, and to focus investment in regions with the greatest development need, for projects registered after 2012, the European Union Emissions Trading System (EU ETS) will only accept CERs from CDM projects hosted in Least Developed Countries (LDCs) [17]. Offset program administrators have noted that the new EU policy could significantly shift the CDM project portfolio. While this could provide new opportunities for improved cookstove projects in LDCs, there is also a considerable need for such projects in more-developed countries such as Kenya, Nigeria and India, where $80 \%, 74 \%$, and $66 \%$ of the population, respectively, still relies on traditional biomass for cooking [1].

Assuming that these challenges can be overcome, there is still a significant barrier that cookstove projects must surpass in order to access carbonmarket finance and to ensure environmental integrity: they need credible, scientifically robust methodologies to measure and verify their emission reductions. This paper reviews existing carbon market methodologies for improved cookstove projects, drawing on a literature review as well as interviews with market actors and technical experts, including project developers, offset program administrators, cookstove engineers, and researchers. Interviews followed a semi-structured interview format, with all interviews conducted over the phone using a standard interview guide developed in advance with questions and themes to be explored. Based on this review, we 
identify key knowledge gaps and areas for additional research that can help to accelerate the development and implementation of improved cookstove projects, and the local and global benefits they can bring. While this paper focuses on project-based offset methodologies, the findings will also be relevant for other carbon finance mechanisms such as Nationally Appropriate Mitigation Actions (NAMAs), broader sectoral crediting mechanisms, or non-crediting mechanisms that involve quantification of GHG benefits.

\section{Review of Current Carbon Market Activity}

Carbon offsets play a role in both compliance and voluntary carbon markets. In compliance markets, such those created by the Kyoto Protocol or the EU Emissions Trading System, governments and regulated facilities have mandatory, legal emission obligations, and can use offsets, such as CERs, as an alternative to reducing their own emissions. The CDM is currently the only program that can issue offsets from developing countries for use in compliance markets. In contrast, voluntary market offset programs such as the Gold Standard (GS), the American Carbon Registry (ACR), and the Verified Carbon Standard (VCS) issue offsets that can be used by businesses, governments, nongovernmental organizations, and individuals electing to offset their emissions for other reasons, such as corporate or individual social responsibility.

All four of these programs (and no others) have enabled crediting of emission reductions from improved cookstove projects. Each has approved methodologies or protocols that specify eligible technologies and project types, and the means by which projects are monitored and their emission reductions quantified. The methodologies apply to projects that are introducing a stove technology and consider the emissions savings from reducing or displacing the use of non-renewable biomass for household heating and cooking. Here we define non-renewable biomass as biomass production that is not sustainably managed and results in a decrease in carbon stocks over time [18].

Under the CDM, two methodologies are available. AMS II.G applies to cases where an improved-efficiency cookstove is introduced to reduce the demand for nonrenewable biomass. AMS I.E applies to cases where a renewable technology, such as biogas or solar cookers, is introduced to displace use of non-renewable biomass. Note the AMS I.E methodology is considered here because the baseline scenario approach is very similar to AMS II.G. However, the project scenario approaches under AMS I.E of introduction of new renewable energy technologies are not explored in this paper. The Gold Standard allows project developers to use one of the two CDM methodologies as long as they meet additional stakeholder consultation and sustainable development co-benefit requirements. The
Gold Standard also has its own methodology that applies to projects that decrease or displace GHG emissions from thermal energy consumption in households or non-domestic facilities, but unlike the CDM methodologies, may include improved fossil fuel (in addition to improved biomass) technologies [19]. The American Carbon Registry's cookstove methodology is a modified version of AMS I.E, with expanded applicability and modified calculation and monitoring methodologies. The Verified Carbon Standard does not have its own cookstove methodology, but allows the use of approved CDM methodologies. Table 1 outlines the specific methodologies and applicable versions evaluated in this paper, which are discussed in greater detail in Section 3.

Nearly all improved-cookstove offset projects are registered or in the project pipeline under either the Gold Standard or the CDM. As shown in Figure 1, approved and under-development cookstove projects are expected to yield more than 10 million offset units over their first crediting periods (7 or 10 years). To date no projects have been developed under the American Carbon Registry, and only one project, using the CDM methodology AMS I.E., has been developed under the Verified Carbon Standard, in Cambodia.

Even though over half of the projected volume of credits generated will be CERs under the CDM, the Gold Standard plays a pivotal role in the market for cookstove offsets. Close to $40 \%$ of projected CERs generated under the CDM also aim to be certified under the Gold Standard. These projects have been developed using the CDM methodology and have applied the additional Gold Standard stakeholder and sustainable development requirements to receive Gold Standard certification. This is distinct from projects which have been developed using the standalone Gold Standard improved cookstove methodology. Together, Gold Standard Verified Emission Reductions (VERs) and Gold Standard-certified CERs account for over three-quarters of the offsets projected to be generated from improved cookstove projects. That the vast majority of cookstove projects have achieved this additional certification demonstrates the perceived added value of Gold Standard label, and its associated stakeholder and sustainable development processes.

The geographic distribution of cookstove projects is notable. While across all project types in the CDM pipeline, less than $5 \%$ of credits are generated from projects in Africa, over $65 \%$ of emission reductions from improved cookstove projects are based in Africa (see Figure 1). The Asia and Pacific region, which makes up close to $80 \%$ of the total CDM pipeline across all project types, comprises only $30 \%$ of improved cookstove project types [20]. Just 4\% of emission reductions from improved cookstove projects are based in Latin America (Figure 1). 


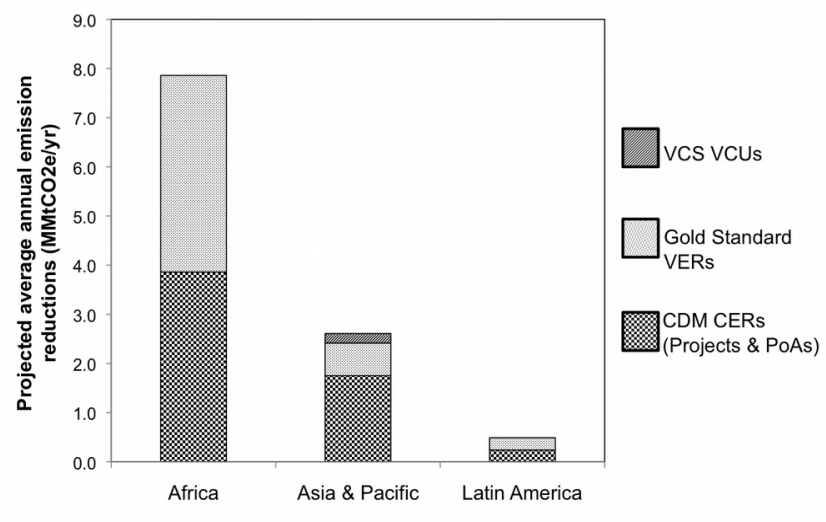

Figure 1. Projected average annual offset volume of projects accepted and under development across programs.

Note: data are projected offset volumes based on estimates in project design documents. Data include projects categorized as household energy efficiency projects. We include CDM registered, registration requested or at-validation projects that apply either the AMS II.G and/or I.E methodologies [20]. We include Gold Standard VERs projections from issued, registered, validated or listed projects [21]. We include registered and issued VCS projects, per the VCS Projects Database, [22].

These trends follow estimates of per capita fuelwood consumption, which are considerably higher in Africa than in Asia and South America [23].

Close to half of the projected CERs from projects in Africa come from five countries: Burundi, Zambia, the Democratic Republic of Congo, Ghana and Kenya. Well over half of the CERs from the Asia and Pacific region come from India, Nepal and Pakistan. In Latin America, the largest projects under development are in El Salvador and Honduras. Mueller et al. (2011) found Benin, Burkina Faso, Cambodia, Mali, Mozambique, Niger, and Zambia to be among the countries best-suited to improved cookstove projects based on an assessment of charcoal production and consumption, deforestation rates, the percentage of total national energy consumption that is met by traditional biomass, and the interest from host country agencies in encouraging cookstove projects.

With a geographical shift in focus to projects developed in LDCs (to meet the EU ETS' acceptance of only CERs generated in LDCs after 2012), it is worth noting that already nearly half of all household energy CERs accepted and under development under the CDM come from LDCs [20]. In contrast, under the Gold Standard, only $10 \%$ of the projected offsets (VERs) issued are from LDCs [21]. Most of projected
African VERs are from non-LDC countries: Kenya, Nigeria and South Africa.

Household energy efficiency projects (including improved cookstove projects) make up only $1.2 \%$ of CDM projects in the pipeline and are expected to produce less than $0.5 \%$ of CERs issued per year. However, this could change with the refocus on LDCs in the EU ETS after 2012.

As shown in Figure 2, the number of projects, both individual and Program of Activities (PoAs), has increased considerably since methodologies were first approved in 2008. A PoA is a "voluntary coordinated action by a private or public entity which coordinates and implements any policy/measure or stated goal (i.e. incentive schemes and voluntary programmes), which leads to anthropogenic GHG emission reductions or net anthropogenic greenhouse gas removals by sinks that are additional to any that would occur in the absence of the PoA, via an unlimited number of CDM programme activities" [24]. PoAs represent an aggregated approach that enables multiple project activities to be registered through a single approval process, offering lower transaction costs and increased scalability. Because of their larger size, PoAs are expected to deliver the large majority (over three-fourths) of cookstove CERs. Despite the increased project development activity, registration of projects and issuance of credits has been limited. To date only 11 individual, and no PoA, cookstove projects have been registered and just over 54,000 CERs have been issued [20]. Furthermore, the average issuance success rate of these projects has only been $20 \%$, in comparison to credit volumes projected in project design documents [20].

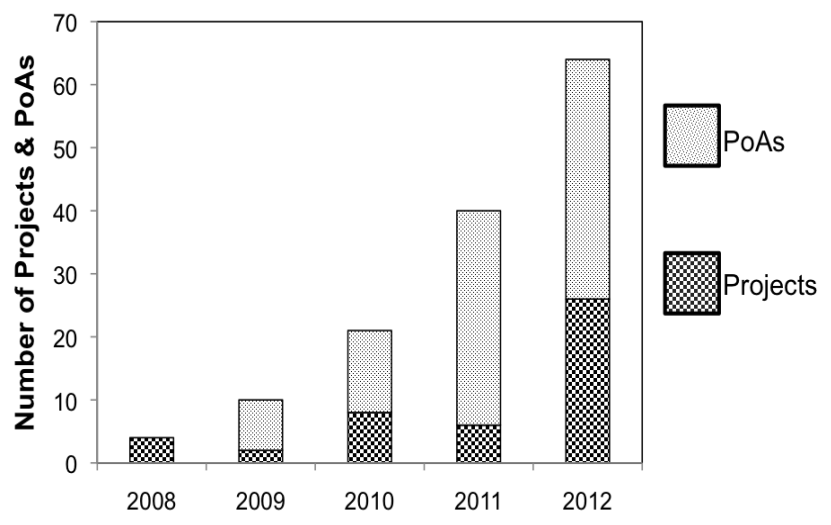

Figure 2. Number of CDM projects and PoAs submitted each year since methodologies (AMS I.E and AMS II.G) were approved in 2008.

Note: projects include those applying either the AMS II.G or I.E methodologies. Years are approximated using the start date of the public comment period under validation. Source: UNEP Risoe Centre [20]. 
Table 1. Improved cookstove carbon crediting methodologies reviewed.

\begin{tabular}{|c|c|c|c|}
\hline Program & Gold Standard & CDM (and VCS)-AMS II.G & $\begin{array}{l}\text { CDM (and VCS)- } \\
\text { AMS I.E }\end{array}$ \\
\hline $\begin{array}{l}\text { Methodology } \\
\text { version } \\
\text { reviewed }\end{array}$ & Version 1.0, 11/04/2011 [19] & Version 05 UNFCCC [25] & $\begin{array}{l}\text { Version } 05 \\
\text { (UNFCCC 2012a) }\end{array}$ \\
\hline Applicability & $\begin{array}{l}\text { Introduction of } \\
\text { technologies/practices that } \\
\text { reduce or displace GHG } \\
\text { emissions from thermal energy } \\
\text { consumption by households, } \\
\text { institutions, commercial or } \\
\text { industrial premises }\end{array}$ & $\begin{array}{l}\text { Introduction of high-efficiency } \\
\text { thermal appliances utilizing } \\
\text { non-renewable biomass or } \\
\text { retrofitting existing units to } \\
\text { reduce the use of non- } \\
\text { renewable biomass }\end{array}$ & $\begin{array}{l}\text { Introduction of renewable energy technologies that } \\
\text { displace the use of non-renewable biomass }\end{array}$ \\
\hline $\begin{array}{l}\text { Measure of } \\
\text { biomass fuel } \\
\text { consumption }\end{array}$ & $\begin{array}{l}\text { Kitchen Performance Test } \\
\text { (KPT) }\end{array}$ & \multicolumn{2}{|c|}{$\begin{array}{l}\text { Three options: Kitchen Performance Test (KPT), Water Boiling Test (WBT), or Controlled } \\
\text { Cooking Test (CCT) }\end{array}$} \\
\hline $\begin{array}{l}\text { Fraction } \\
\text { non- } \\
\text { renewable } \\
\text { biomass }\end{array}$ & $\begin{array}{l}\text { Quantitative assessment based } \\
\text { on estimates of mean annual } \\
\text { increment (MAI) and woody } \\
\text { biomass harvest for the area } \\
\text { where fuel is collected; or } \\
\text { qualitative assessment based } \\
\text { on satellite imagery and field } \\
\text { surveys; follow CDM AMS II.G }\end{array}$ & \multicolumn{2}{|c|}{$\begin{array}{l}\text { Project-specific surveys or default } f_{N R B} \text { values for LDCs, Small Island Developing States } \\
\text { (SIDS) and countries with less than } 10 \text { registered CDM projects as of } 31 \text { December } \\
\text { 2010. based on national-level assessment of mean annual increment (MAI) and total } \\
\text { harvest }\end{array}$} \\
\hline $\begin{array}{l}\text { Baseline } \\
\text { scenario }\end{array}$ & $\begin{array}{l}\text { Typical baseline fuel } \\
\text { consumption patterns in target } \\
\text { population adopting the } \\
\text { project technology }\end{array}$ & $\begin{array}{l}\text { Assume use of fossil fuel to } \\
\text { meet demand for } \\
\text { cooking/heating }\end{array}$ & $\begin{array}{l}\text { Assume use of fossil fuel to meet demand for } \\
\text { cooking/heating }\end{array}$ \\
\hline $\begin{array}{l}\text { GHGs } \\
\text { included in } \\
\text { project } \\
\text { boundary }\end{array}$ & $\begin{array}{l}\mathrm{CO}_{2} \text {, methane }\left(\mathrm{CH}_{4}\right) \text {, nitrous } \\
\text { oxide }\left(\mathrm{N}_{2} \mathrm{O}\right)\end{array}$ & $\mathrm{CO}_{2}$ & $\mathrm{CO}_{2}$ \\
\hline $\begin{array}{l}\text { Project types } \\
\text { covered }\end{array}$ & $\begin{array}{l}\text { Adoption of project technology } \\
\text { to reduce fuel consumption in } \\
\text { target population }\end{array}$ & $\begin{array}{l}\text { Installation of more-efficient } \\
\text { thermal appliances to reduce } \\
\text { use of non-renewable biomass }\end{array}$ & $\begin{array}{l}\text { Use of renewable energy technologies for thermal } \\
\text { energy to displace the use of non-renewable biomass }\end{array}$ \\
\hline Additionality & $\begin{array}{l}\text { Either CDM additionality tool } \\
\text { [27], CDM small scale project } \\
\text { guidelines (as for AMS-II.G } \\
\text { and I.E) [28], or } \\
\text { demonstration that technology } \\
\text { is "first of its kind" ( }<20 \% \\
\text { adoption rate in target area) }\end{array}$ & \multicolumn{2}{|c|}{$\begin{array}{l}\text { Either:1) located in LDC/SIDS or special designated under developed zone of host } \\
\text { country [28]; 2) annual energy savings are less than } 600 \mathrm{MWh} \text { and end users are } \\
\text { households/communities [28]; 3) each unit is no larger than } 5 \% \text { of the small-scale CDM } \\
\text { threshold ( } 750 \mathrm{~kW} \text { installed capacity or } 3,000 \mathrm{MWh} \text { energy savings per year or } 3,000 \\
\text { metric tons emission reductions per year), and end users are households/communities } \\
\text { [28]; }\end{array}$} \\
\hline Leakage & $\begin{array}{l}\text { Methodology specifies several } \\
\text { potential sources of leakage to } \\
\text { be investigated. If found that } \\
\text { non-project households } \\
\text { increase their fuel } \\
\text { consumption as a result of the } \\
\text { project, then calculations must } \\
\text { be adjusted. }\end{array}$ & \multicolumn{2}{|c|}{$\begin{array}{l}\text { Must consider the increase in the use of non-renewable woody biomass by non-project } \\
\text { households through ex-post surveys of users and the areas where non-renewable woody } \\
\text { biomass is sourced. If it is found that use increases, the estimate of quantity of wood } \\
\text { saved must be adjusted. }\end{array}$} \\
\hline
\end{tabular}




\section{Three Key Parameters in Improved Cookstove Methodologies}

This paper reviews the methodologies currently available for crediting emission reductions from improved cookstove projects. Table 1 below compares the various program features of the pertinent CDM, Gold Standard, VCS, and ACR methodologies. These improved cookstove methodologies fall under one of two types: improved energy efficiency (e.g., CDM's AMS-II.G) or fuel switching to renewable energy (e.g., the CDM's AMS-I.E). ACR's cookstove methodology adapts AMS-I.E. and focuses on fuel switching. VCS allows use of CDM methodologies and thus applies to both project types. The Gold Standard methodology could apply to both improved efficiency and fuel switching, though this paper focuses on the efficiency projects.

Projects that focus on improving the energy efficiency of cookstoves (using AMS-II.G) account for nearly $80 \%$ of CDM cookstove projects, over two-thirds of the cookstove offsets issued to date (see Figure 1). To give a sense of typical CDM projects, one Nigerian project involved distribution of up to 12,500 efficient wood stoves in the Guinea Savannah Zone, where deforestation has become a concern (e.g. [29]). The Turbococinas rural cooking stove substitution PoA in El Salvador [30]where the use of fuelwood for cooking has helped drive some of the worst deforestation in Latin Americadistributed over 100,000 stoves that were designed to use small pieces of wood from tree trimmings which avoids cutting down whole trees.

While less common than stove efficiency projects, several CDM projects have involved a switch from nonrenewable biomass fuel to renewable sources (using methodology AMS-I.E). In Zambia, for example, one CDM project involved switching from stoves using nonrenewable charcoal to stoves using small sticks from renewable biomass sources in 30,000 households in Lusaka City [31]. In rural Rwanda, a CDM project introduced four solar photovoltaic water treatment plants to displace the use of non-renewable fuelwood to boil water [32]. The CDM-supported Biomass Support Program in Nepal distributed 20,000 biogas stoves and digesters to displace use of non-renewable firewood [33].

In both types of cookstove projects-improved efficiency and fuel substitution-emission reductions are calculated as the product of the amount of woody biomass saved, the fraction that is considered nonrenewable biomass, the net calorific value (NCV) of the biomass, and an emission factor for the fuel used. The CDM methodologies AMS II.G and AMS I.E provide the following equation for calculating emission reductions:

$$
E r_{y}=B_{y} \times f_{N R B, y} \times N C V_{\text {biomass }} \times E F_{\text {proj.fossilfuel }}
$$

Where:

$E R_{y}=$ Emissions reductions during year $y$ in $\mathrm{tCO}_{2} \mathrm{e}$

$B_{y,}=\quad$ Quantity of woody biomass saved (or substituted or displaced), in tons

$f_{N R B, y}=\quad$ Fraction of woody biomass saved by the project activity in year $y$ that can be established as non-renewable biomass

$N C V_{\text {biomass }}=$ Net calorific value of the non-renewable woody biomass that is substituted (Intergovernmental Panel on Climate Change default for wood fuel, $0.015 \mathrm{TJ} /$ ton)

$E f_{\text {proj_fossitiel }}=$ Emission factor for the substitution of non-renewable woody biomass by similar consumers.

The methodologies follow similar approaches regarding evaluation of the project scenario, additionality and leakage, as shown in Table 1 . Consequently, these parameters are not addressed in further detail here. Since the net calorific value of the non-renewable biomass ( $\left.N C V_{\text {biomass }}\right)$ is relatively straightforward-it is empirically measurable and a default value from the Intergovernmental Panel on Climate Change (IPCC) exists-this variable is also not considered further.

Methodologies differ in their approaches to three primary inputs required for calculation of the emission reductions from this project type: biomass fuel consumption $\left(B_{y}\right)$, fraction of non-renewable biomass $\left(f_{N R B}\right)$, and emission factors for fuel combustion ( $E_{\text {proj_fossifuel; }}$ Table 3 ). The method and assumptions used in estimating each of these variables contributes to uncertainty in the calculation of emission reductions. A study by Johnson et al. (2010) [34] assessed the relative contributions of the three variables to the overall uncertainty in carbon offset estimation for an improved cookstove project in Mexico. The study found that fuel consumption $\left(B_{y}\right)$ contributed to $28 \%$ of the uncertainty, while the fraction of non-renewable biomass $\left(f_{N R B}\right)$ contributed $47 \%$, and emission factors ( $E f_{\text {proj fossiffuel) }}$ accounted for $25 \%$.

In the following sub-sections, we focus on the quantification of these three parameters:

- Estimating biomass fuel savings (Section 3.1);

- Assessing of the impact of biomass consumption on above-ground carbon stocks (Section 3.2); and

- Estimating $\mathrm{CO}_{2}$ emissions from cookstoves (Section 3.3). 
Table 2. Comparison of biomass fuel consumption testing approaches.

\begin{tabular}{lll}
\hline Test name & Type of test and what it measures & Strengths \\
\hline Kitchen & Community test (in households); measures fuel use & Typically conducted in actual \\
Performanc & in households based on normal cooking tasks over & stove dissemination effort with \\
e Test & several days. & local cooks. Best way to \\
(KPT) & The approach using the KPT simply subtracts the & understand stove's impact on \\
& quantity of woody biomass used by project & fuel consumption, as well as \\
& participants (based on a random sample) from the & household characteristics and \\
& amount of biomass used by a representative & behaviors as it occurs in the \\
& sample of non-participant households. Both are & user's household. Provides a \\
& measured over a three-day period. Total biomass & consistent approach for \\
& available in the household is weighed at the start & estimating both baseline and \\
& and end of each day or meal to measure the weight & project biomass consumption. \\
& of fuel used.
\end{tabular}

Water Laboratory test; assesses stove performance while

Boiling Test completing a standard task (boiling and simmering (WBT) water).

The approach relying on the WBT calculates the biomass savings based on the amount of biomass used in the absence of the project, and the relative efficiencies of the new and replaced stoves. The efficiency of the system being replaced is measured with representative sampling methods, published values or default values. Efficiency of the new system being deployed under the project activity is determined by the WBT. Data for improved stoves is provided by the stove manufacturer.
Weaknesses

Measurements more uncertain as possible sources of error are difficult to control compared with laboratory tests.
Simple method that can be performed on most stoves worldwide (standardized and replicable). Provides a preliminary understanding of stove performance, useful during design.
Reveals technical stove performance, not necessarily what can be achieved in actual households while cooking actual foods. Relies on default values for baseline cookstove biomass consumption.

\section{Controlled \\ Cooking \\ Test (CCT)}

Laboratory test, performed by a local cook on location or in-field in a test kitchen; measures stove performance using actual local cooking methods as a cook prepares a typical meal intended to be representative of cooking practices of the target population participating in the project.

The approach using the CCT calculates the biomass savings based on the relative specific fuel consumption or fuel consumption rates of the baseline and replacement systems. The fuel consumption rate (fuel consumed per item processed (e.g. food cooked) or per amount of time) is determined by using the CCT.
Stoves are assessed while performing a standard cooking task (more closely mimics actual cooking done by local users). Test design helps minimize influence of potential confounding factors and allows for conditions to be reproduced.
Demonstrates what is possible under ideal conditions, but not necessarily what occurs under daily use.

Sources: [35-37]. 


\subsection{Estimating Biomass Fuel Savings: $B_{y}$}

The amount of woody biomass saved, defined as the reduction in biomass consumption with the introduction of an improved cookstove (either through efficiency gains or fuel switching), is one of the key data inputs for quantifying emission reductions from projects and is a source of uncertainty for project developers. Under CDM methodologies AMS II.G and AMS I.E, the quantification of emission reductions (see Section 3 ) relies on the factor $B_{y,}$, representing the "quantity of woody biomass that is saved" or reduced by the project activities $[25,38]$.

CDM methodology AMS II.G presents project developers with three options for quantifying biomass fuel savings from improved stoves: the Kitchen Performance Test (KPT), the Water Boiling Test (WBT), and the Controlled Cooking Test (CCT). Table 2 describes each of these methods, along with their strengths and weaknesses. In contrast to the other two laboratorybased methods, the Kitchen Performance Test is done in the field, and can thus better represent stove users' actual cooking behaviour. The Gold Standard methodology only allows the use of the KPT. However, KPT measurements are subject to large uncertainties as, compared with laboratory tests, it can be difficult to control sources of error. The primary advantage of the Water Boiling Test is its simplicity; the laboratory-based method is standardized and replicable. However, the laboratory results on stove performance do not necessarily translate to cooking actual meals in households, and thus the accuracy of this method is frequently called into question. Meanwhile, the Controlled Cooking Test protocol provides a compromise, better representing local cooking while being conducted in a controlled environment.

For each of these options, the quantity of woody biomass used in the absence of the project is calculated in one of two ways. The first method is using historical data or local surveys of the estimated annual average consumption of woody biomass per appliance. The second method is quantification based on the amount of thermal energy generated by the project, net calorific value of biomass fuel and the replacement system efficiency.

Detailed guidelines for performing each of the tests have been developed and tested in laboratory and field studies. While the CDM methodology allows flexibility in the selection of the stove test, cookstove experts interviewed for this paper expressed concerns about the accuracy of some tests, especially the WBT. As highlighted in Table 2 and Figure 3, there are a number of trades-offs related to accuracy versus degree of complexity and costs. Fuel consumption can be driven by myriad factors (e.g., geography, climate, and cooking practices), making it highly difficult to develop an adequate one-size-fits-all estimation approach [39].
Increasing costs, sample size, variability, measurements in housholds

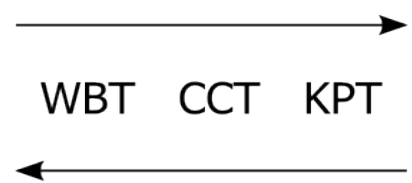

Increasing control of variables, isolation of stove performance, quantification of emissions, intervention of testers

Figure 3. Relative benefits and trade-offs of biomass use quantification approaches.

Source: Adapted from Aprovecho Research Center [39].

Emission factors calculated from water boiling tests do not always reflect household emissions from daily cooking activities [40,41]. Johnson et al. [42] found that under daily-use conditions, improved Patsari stoves developed for use in rural Mexico performed significantly worse relative to open fires in WBT tests than they had in simulated kitchens-but they also performed significantly better in daily use when making tortillas-a far more common activity. Thus the WBT proved inadequate on multiple levels. Berrueta et al. [43], meanwhile, evaluated Patsari stoves using all three tests, and found the WBT "gave little indication of the overall performance of the stove in rural communities". The CCT, focused on tortilla-making, was somewhat more predictive of the fuel savings found by the KPT (44-65\% for CCT vs. $67 \%$ for KPT). Thus, the researchers concluded, field-testing stoves "is of critical importance" [43]. Experts interviewed for this paper offered a similar perspective; as one put it, if there is a correlation between WBT efficiency measures and stoves' real-life performance, "we haven't yet found it".

Published studies and project developers interviewed generally agree that the KPT is a more robust way to determine whether new cookstoves actually provide fuel savings. Johnson et al. (2010) [34] suggest that although community level sampling requires additional effort and costs, it is also likely to deliver a larger volume of offset credits, which can then more easily absorb the higher transaction costs. However, market actors interviewed noted that most project developers, when using the CDM methodology, use the WBT, because it is cheaper and easier to implement, with default values provided by the stove manufacturer. The decision to use the WBT vs. KPT may also depend on the project size: project developers said that for a larger-scale project or PoA, the KPT is likely to be much less feasible and they are more likely to use the WBT approach. Technical experts also noted that there may be ways to reduce the cost of a KPT, such as having local NGOs perform the tests rather than hiring expensive international consultants. 
To the extent that the WBT is still used, it can be improved. Quantification relies on values for baseline fuelwood consumption and for the efficiency of the traditional stove being replaced (this is also true for the CCT). The CDM methodology provides default efficiency values for two traditional stove types-a three-stone fire, or a conventional system with no improved combustion -as well as a default efficiency value for devices with improved combustion air supply or flue gas ventilation. Experts interviewed noted that these limited defaults do not cover the range of cookstoves in most countries. Market actors interviewed suggested developing conservative default values for these parameters to use instead of in-field values, to reduce uncertainty. The CDM Small-Scale Working Group (CDM SSC WG) recently considered doing so, but decided not to proceed because the huge variation in available data estimates made the use of regional default values infeasible [44]. Though more logistically complicated, and time-and source-intensive, testing stoves outside of a controlled laboratory setting and using a variety of typical cooking activities, as is done in the KPT, appears to be an important factor in ensuring accurate and credible results in the baseline or default analysis.

While in some respects, the CCT can be considered a compromise between the less-accurate WBT and moreburdensome KPT, experts still cite a number of issues with this test. As noted above, the CCT is usually done in a simulated kitchen (or at least in the same kitchen as the traditional stove comparison test), and it is generally considered a laboratory test, like the WBT, more controlled than the KPT. However, evaluating one cooking task does not accurately represent stove performance and fuel use in households' actual daily cooking activities. While the CCT does more accurately measure fuel consumption in the performance of particular cooking tasks than the WBT, it cannot easily be compared across regions or types of food [43]. It has been suggested that although the CCT offers benefits of reduced costs from field testing relative to the KPT, these gains are likely outweighed by the added uncertainty in the CCT approach and the potential for corresponding reductions in carbon offsets generated [34].

AMS II.G monitoring requirements include checking the efficiency of the stoves (all, or a representative sample) and confirming at least every two years that the stoves are still in use. Additional stove monitoring is required annually (or biennially if project proponents can demonstrate no significant efficiency losses in the new device), with the specific factor to be monitored depending on which test protocol is used (fuel consumption for the KPT, efficiency for the WBT, and specific fuel consumption for the CCT). One challenge in monitoring is determining the extent to which the new stoves have replaced the old. There is an assumption that new stoves meet all cooking needs, but technical experts interviewed have found that this is "definitely not the case" and results in an overestimation of new stove use. Monitoring under the CDM requires that the traditional stove either be disposed of or not used; otherwise it must be monitored to ensure fuelwood consumption from that stove is excluded from baseline consumption estimates. Monitoring the continued use of traditional stoves is a challenge; technical experts said better alternatives are needed. The KPT test does help address the replacement issue better than the WBT; since the KPT will measure real fuel usage across all stoves used by the household, market actors interviewed have found that it can provide a more accurate picture.

One recent proposal for monitoring stove usage noted by a project developer is the use of data loggers affixed to stoves. Temperature sensors, including the Stove Use Monitoring System, also known as SUMS, developed by Prof. Kirk Smith's research group at the University of California-Berkeley and sold by Berkeley Air, have the potential to more accurately capture data on stove usage. Moreover, several technical experts have noted that combining data logger output with the KPT could generate more comprehensive estimates of fuel consumption. There are still some issues concerning data loggers, such as how to be sure they are truly randomly dispersed among the cookstoves distributed, while at the same time remaining geographically consolidated to facilitate downloading data from loggers locally. Project developers interviewed noted that methodologies do not currently have a mechanism to incorporate data logger information into monitoring.

Program administrators interviewed see great potential in data loggers to address challenges in project monitoring. Managing transaction costs associated with implementation of sampling plans and precision requirements is highlighted as very important for the success of future projects. Regulatory documents, including sampling standards and best practice examples, have been developed for monitoring sampling and surveying. However, program administrators indicated that implementation of monitoring plans continues to pose many challenges for projects and is likely a contributor to the modest issuance success rates observed by projects so far.

In response, a request has been made to the CDM Executive Board by the Conference of the Parties serving as the meeting of the Parties to the Kyoto Protocol (CMP) to consider revising the monitoring requirements, including provisions for how to deal with missing survey data. One concern raised is that none of the current methodologies incorporate uncertainties in estimates of fuel usage. Johnson et al. [34] critique the Gold Stan Standard dard and CDM methodologies for not following the Guidelines for National Greenhouse Gas Inventories (Tier III) nor the Good Practice Guidance and Uncertainty Management in National Greenhouse Gas Inventories "by allowing non-representative inputs and not accounting for uncertainty in offset estimates". 
Instead, they suggest that IPCC recommendations for uncertainty from the Good Practice Guidance and Uncertainty Management in National GHG Inventories should be applied to project emission reductions calculations [45].

\subsection{Assessing of the Impact of Biomass Consumption on Carbon Stocks: $f_{N R B, Y}$}

Cookstove offset projects are premised on the notion that improved stove efficiency or fuel substitution reduces the use of non-renewable biomass. The factor $f_{N R B}$ represents the "fraction of woody biomass saved by the project activity in year y that can be established as nonrenewable biomass" [25], and is a key variable in all current cookstove offset methodologies. Yet determining the fraction of biomass use that a cookstove project will avoid that involves non-renewable biomass is perhaps the most difficult challenge for offset crediting methodologies. How offset methodologies estimate the carbon emissions from biomass combustion stands in contrast to standard emissions accounting approaches, in particular, those established by the UNFCCC used in national inventories. Under these traditional accounting approaches, the combustion of biomass, whether or not it is considered renewable, is considered to have no net $\mathrm{CO}_{2}$ emissions impact. Instead, the impact of combustion of non-renewable biomass is expected to be manifested in a corresponding long-term reduction in carbon stocks in forests and other lands.

With renewable biomass, trees and plants are expected to ultimately fully regrow, resulting in no net long-term change in atmospheric $\mathrm{CO}_{2}$ concentrations. In contrast, when biomass comes from forests or nonforest areas that are not sustainably managed, and where deforestation and/or land degradation may be occurring, the $\mathrm{CO}_{2}$ released through biomass combustion will not be offset by new growth.

Based on its definition of renewable biomass [46], the CDM Executive Board has identified several indicators of scarcity to help identify non-renewable biomass. Woody biomass is considered non-renewable if at least two of the following indicators are shown to exist:

- A trend showing an increase in time spent or distance travelled for gathering fuelwood, by users (or fuelwood suppliers) or alternatively, a trend showing an increase in the distance the fuelwood is transported to the project area;

- Survey results, national or local statistics, studies, maps or other sources of information, such as remotesensing data, that show that carbon stocks are depleting in the project area;

- Increasing trends in fuel wood prices indicating a scarcity of fuel-wood;
- Trends in the types of cooking fuel collected by users that indicate a scarcity of woody biomass (UNFCCC 2011b; 2012a).

Specific approaches and guidelines for quantifying the fraction of non-renewable biomass vary across the protocols. Until recently, CDM methodologies included only guidance on determining $f_{N R B}$ based on the above definition, but no specific quantification approaches or default factors. The lack of a standardized approach for determining the $f_{N R B}$ value for projects was considered a source of uncertainty for-and a barrier to-project development, by both technical experts and market actors interviewed (see, e.g., [8]).

Across the board, consistent accounting methods are considered critical to demonstrating the credibility of these carbon market projects [8]. A study by Johnson et al. (2010) [34] found that differences in approaches for quantifying $f_{N R B}$ contributed $47 \%$ to the overall uncertainty of emission reductions generated for an improved cookstove project in Mexico. The scale of data selected in estimating $f_{N R B}$ can potentially introduce error; for instance, if national-level data are used, as they are for the default values, they may be too aggregated, given potentially wide variations among local communities. According to one technical expert, a survey of CDM cookstove project design documents (PDDs) found that most projects based their $f_{N R B}$ assessment on national-level data on mean annual increment of forest growth and total wood harvest. The survey results also suggested that projects were not consistent in data sources cited; many loosely cited "literature" without referencing specific data sources. Very few conducted their own project-specific survey of $f_{N R B}$, and on average, the preliminary survey found the $f_{N R B}$ claimed by projects was close to $80 \%$ (with $100 \%$ being all non-renewable).

As part of the effort to improve and further standardize $f_{N R B}$ assessments, the CDM Executive Board issued a call for public input on two proposed approaches for quantification of $f_{N R B}$ at its 63rd meeting in September 2011: one based on the Woodfuel Integrated Supply/Demand Overview Mapping (WISDOM) methodology, and another based on mean annual increment (MAI). The WISDOM method determines the $f_{N R B}$ at a sub-national level, "by incorporating spatial variations of the biomass and population data for the given geographic areas from which the woody biomass is extracted, their sustainable production capacity and their existing management systems" [47]. The MAI approach determines aggregate country-specific values of $f_{N R B}$ based on the difference between the fuelwood consumption of households and the adjusted MAI of biomass growth [47].

Johnson et al. [34] and Reddy [48] suggest that by 
generating more localized assessments, the WISDOM model could produce more accurate estimates of $f_{N R B}$. Johnson et al. [42] suggest that regional or national average $f_{\text {NRB }}$ figures based on MAI risk underestimating the carbon emission reductions. Results from Johnson et al. [8] found that for one village in Mexico, a community-scale application of the WISDOM model estimated the $f_{N R B}$ at $85 \%$, while using the WISDOM model to develop a broader regional average [49] resulted in an $f_{N R B}$ of only $20 \%$-not reflective of the situation in the village. Indeed, as Johnson et al. [34] note, the community-level analysis approach supports the targeting of stove projects to communities where biomass scarcity is greatest and the rates of improved cookstoves are likely to be higher.

Despite these advantages, the WISDOM model, as noted by some stakeholders, is a complex tool, with significant data requirements, and the need for many project-specific assumptions $[48,50]$. Furthermore, the WISDOM model was designed for rural woodstove projects where households gather their own fuelwood. Applicability of the model to urban fuelwood projects is less obvious [51]. Nevertheless, technical experts interviewed suggested that the tool could conceivably be used to simulate impacts on "fuelsheds" used to produce wood fuels (including charcoal) that are transported to urban areas.

In 2012, the CDM Executive Board issued national default factors for $f_{N R B}$ based on a highly aggregated MAI approach $[38,52]$. Under this approach, the $f_{N R B}$ values were calculated for nearly 100 countries, based on the total annual national biomass removals minus the portion of demonstrably renewable biomass from growth in protected reserve areas. (Note that this approach does not distinguish removals for timber harvesting from those for fuelwood.) The large majority (over four-fifths) of default values exceed $80 \%$, with the remainder ranging from $40 \%$ to $77 \%$. Before the default values can be applied by a project, they must be approved by designated national authority of the host county, as of March 2013, only 18 countries had given approved their default values [52].

Several market actors interviewed characterize development of default $f_{N R B}$ values as a "huge triumph", since avoiding the need to establish new $f_{N R B}$ values for each project can greatly reduce project development costs and quantification uncertainty. According to the Executive Board decision, project proponents have the choice of using these "conservative country-specific default values" or determining "project-specific values by undertaking a study in the project region as prescribed in the methodology" [28]. As a result, many project developers are unlikely to incur the added costs of such a study, especially given the high values for most country-specific defaults.

However, despite support for standardized default values, there is recognition by market actors and researchers interviewed that relying on national-level forest growth and total harvest removals may not be appropriate for estimating whether or not fuelwood and wood products in general are renewable. Some project developers said the national-level default values are "too conservative" and do not reflect conditions in the targeted regions where they are operating, and as a result they find it worthwhile to develop their own project-specific values to maximize their emission reduction credits. Others have critiqued the use of national-level estimates given the poor data quality, particularly in LDCs, of UN Food and Agriculture Organization (FAO) forest resource assessments data; they have also noted that national-level estimates cannot account for heterogeneous climatic and geographical conditions that impact fuelwood supply and demand, thus leading to an over-or underestimation of the $f_{N R B}$ parameter [50]. It was also suggested that subnational $f_{N R B}$ values should be allowed if and when fuelwood consumption data are reported at a subnational level [48].

Other approaches have been proposed for quantifying the $f_{\text {NRB }}$. The net carbon stock approach compares the household demand for biomass for fuelwood against other possible uses of biomass (e.g. carbon storage, wood products); emissions reductions/removals are calculated as the net change in carbon stocks attributable to reducing fuelwood consumption as compared to the net change in carbon stocks attributable to other uses of wood. Interviewees also noted that new spatially explicit models are under development (e.g. Winrock International's GeoMOD and NRB v1.0, via a collaboration between Yale University and Universidad Nacional Autónoma de Mexico) that consider fuelwood demand and fuel type with dynamic biomass supply sources, as well as incorporating land-use change. Market actors interviewed see integration of alternative quantification approaches to develop sub-national $f_{N R B}$ estimates as an urgent need.

As income rises, households prefer to avoid the drudgery of fuelwood collection and progress to using modern fuels, suggesting to some extent that fuelwood is considered an "inferior good" [23]. However, the suggestion based on default values developed that three-quarters or more of all fuelwood used is not renewable and is directly contributing to deforestation raises a few red flags and deserves some reflection on the history of research on these issues. Following the fossil fuel energy crisis of the 1970s, there was increasing recognition of the reliance of households in the developing world on wood for heating and cooking. Predictions raised the alarm of an impending fuelwood crisis, with massive deforestation and severe impacts on the poor, giving rise to estimates of the fuelwood gap and the urgent need for planting trees to meet projected demand $[23,53]$. However, by the mid-1980s, as the predicted shortages did not occur, questions were raised 
and it was found that the actual supply was grossly underestimated [23]. Some of the underestimate has been explained by lack of consideration of wood available from outside forests (e.g. parks, roadsides), which were often not counted in supply estimates, but continue to deserve further attention in development of national estimates. By the 1990s, revisions to predictions of the fuelwood crisis became widely accepted, and programs to promote fuelwood supply were redirected [23].

Further examination of fuelwood supply and its contribution to deforestation paints a different picture than the $f_{N R B}$ default values under the CDM. Conclusions developed from studies in several countries found that on a national level, fuelwood demand is unlikely to deplete forest resources or reduce forest cover, but localized scarcities do occur where there is an imbalance between demand and availability [23]. Additional studies examining the causes of tropical deforestation have found only weak evidence that fuelwood is a primary driver, and is instead an "occasional cause" in select regions $[23,54]$. While these results do not suggest that fuelwood does not contribute to deforestation, they do indicate a need to perhaps reexamine some of the assumptions underlying these methodologies, especially the current CDM default values.

\subsection{Estimating $\mathrm{CO}_{2}$ Emissions from Cookstoves: Ef proj_fossiftuel}

Under the CDM methodology AMS II.G, the quantification of project emission reductions (see Section 3 ) relies on the factor $E F_{\text {proj fossifuel, representing the fossil }}$ fuel emission factor of "substitution fuels likely to be used by similar users" [25]. The use of fossil fuel emission factors for baseline fuels represents something of a clever workaround to the restriction that the CDM cannot cover avoided deforestation. Nonetheless, it has been roundly criticized. Johnson et al. [34] say it has "no scientific basis, given that wood emits approximately double the $\mathrm{CO}_{2}$ per unit fuel energy compared to LPG or kerosene thus halving possible offsets from nonrenewable harvesting of fuel". Other studies and technical experts interviewed agree that using fossil fuel emission factors has the effect of reducing the CERs claimed, by around $30 \%$. This is down from a $40 \%$ reduction in earlier methodology versions [55]. Emission factors for several fossil fuels are compared with wood in Table 3. The CDM methodology AMS II.G. suggests the use of a weighted average value of 81.6 , representing a mix of $50 \%$ coal, $25 \%$ kerosene, and $25 \%$ LPG.

The reason for using fossil fuel emission factors for cookstove projects is that the Marrakesh Accord allows for non-afforestation project activities to consider a reduction in carbon stocks as emissions, but not to get credits from any increase in carbon stocks [18]. Still, it is an imperfect workaround. For charcoal production, the simplification is stretched beyond reality. As shown in project design documents (e.g. [31]), there is a precedent for calculating wood use by charcoal stoves by multiplying the charcoal volume by six, following the 1996 IPCC accounting guidelines to estimate total biomass consumed (Reference Manual, p. 1.42, [56]). Then baseline emissions are estimated by applying the projected fossil fuel use emissions factor, which in effect assumes that the project displaces fossil fuel use for charcoal production. Despite concerns over the use of fossil fuel emission factors, project developers interviewed recognized that changing this approach in the CDM methodology will be a significant challenge. Revisiting the biomass emissions factor would require an endorsement by the CMP, which would involve a lengthy review period with uncertain outcomes.

\section{Estimating other Emissions and Climate Impacts}

Methodologies vary in the types of cookstove emissions considered eligible for crediting. While all methodologies credit $\mathrm{CO}_{2}$ emissions, only a subset include $\mathrm{CH}_{4}$ and $\mathrm{N}_{2} \mathrm{O}$ and none include short-lived climate forcers, such as black and brown carbon. Emission reductions of these other gases and short-lived aerosols from improved cookstove efficiency could reduce not only the radiative forcing and climate warming impact, but also provide significant co-benefits for health [57].

Under the AMS II.G and I.E methodologies, stove projects can only receive credit for reducing $\mathrm{CO}_{2}$ emissions. Revising this approach has been considered by the CDM SSC WG, but since these methodologies require projects to assume the use of fossil fuel, it becomes inconsistent to include other emissions from future wood combustion. Under the Gold Standard methodology, however, projects may also get credit for reductions in methane and nitrous oxide $\left(\mathrm{CH}_{4}\right.$ and $\left.\mathrm{N}_{2} \mathrm{O}\right)$ emissions [19]. Using the Gold Standard approach, the combined effect of the additional accounting of $\mathrm{CH}_{4}$ and $\mathrm{N}_{2} \mathrm{O}$ emissions from biomass combustion, plus the use of real conditions for the baseline (instead of fossil fuel values as in AMS II.G) can double the estimated emission reductions for stove projects [55]. The exclusion of $\mathrm{CH}_{4}$ and $\mathrm{N}_{2} \mathrm{O}$ emissions accounting, beside potentially under-crediting emission reductions, could also result in incorrect judgements about the relative benefits of different stoves [42]. Project developers interviewed noted that the current effort to develop a modification to the CDM AMS II.G methodology through the American Carbon Registry will allow for the inclusion of $\mathrm{CH}_{4}$ and $\mathrm{N}_{2} \mathrm{O}$ emissions in addition to $\mathrm{CO}_{2}$. 
Table 3. Comparison of fuel emission factors.

\begin{tabular}{lcl}
\hline Fuel & $\begin{array}{l}\text { Fossil fuel emission factor } \\
\left(\mathrm{tCO}_{2} / \mathrm{TJ}\right)\end{array}$ & Source(s) \\
\hline Wood & 121 & Johnson et al. [34] \\
\hline Coal & 96 & CDM methodology AMS II.G. \\
\hline Kerosene & 71.5 & $\begin{array}{l}\text { CDM methodology AMS II.G. } \\
\text { Johnson et al. [34] } \\
\text { IPCC default }\end{array}$ \\
\hline Liquefied petroleum gas (LPG) & 63.0 & $\begin{array}{l}\text { CDM methodology AMS II.G. } \\
\text { Johnson et al. [34] } \\
\text { IPCC default }\end{array}$ \\
\hline $\begin{array}{l}\text { Weighted average } \\
\begin{array}{l}50 \% \text { coal, 25\% kerosene, 25\% } \\
\text { LPG) }\end{array}\end{array}$ & 81.6 & CDM methodology AMS II.G. \\
\hline
\end{tabular}

Emissions factors used in the methodologies rely on IPCC default factors, which express emissions as a function of the energy content of fuels consumed. Researchers and market actors recommend that emissions factors be refined to incorporate in-field emissions data based on the mass rather than the energy content of fuel consumed. Berkeley Air has worked extensively in this area, with support from the U.S. Agency for International Development and the U.S. Environmental Protection Agency, conducting in-field emissions monitoring $\mathrm{CO}_{2}$, carbon monoxide (CO), particulate matter (PM), black carbon, as well as through the development of emissions monitors for PM and $\mathrm{CO}$. There is still more work to be done in this area, however, and data collection is costly [58].

Cookstove emissions also include short-lived aerosols that have a large climate impact but are not yet considered by methodologies. Black carbon, which results from the incomplete combustion of fossil fuels and biomass, has complex effects on climate. Although ground-level concentrations of black carbon are far lower than for $\mathrm{CO}_{2}$, black carbon absorbs one million times more energy per unit mass than $\mathrm{CO}_{2}$, On a global basis, the current instantaneous radiative forcing of black carbon could be close to half that of anthropogenic $\mathrm{CO}_{2}$ [59]. However, this is only one of the ways that black carbon affects the climate. There remains a good deal of uncertainty about black carbon's climate impacts, as it also affects albedo (e.g., when deposited on white snow or ice), absorbs light and leads to faster melting, and also interacts with clouds, altering reflectivity and lifetime [49].

Solid biomass used for cooking and heating is estimated to contribute $25 \%$ of black carbon emissions globally [60]. As black carbon emissions from transport and industry are expected to decline due to planned interventions, the share of black carbon from traditional bioenergy use in developing country households in Asia and Africa is expected to make up close to half of all global black carbon emissions by 2030 [59].
Black carbon and other short-lived climate forcers (e.g., brown carbon [61], carbon monoxide and nonmethane hydrocarbons) are known to contribute to warming, but have been excluded from climate agreements such as the Kyoto Protocol and offset schemes, in part due to their short and complicated life cycles and varied impacts [62]. The argument for using carbon finance to switch from traditional to improved cookstoves "would be even stronger were the non-Kyoto substances and their large short-term impacts considered in this comparison" [62]. Results from an improved cookstove project in Mexico suggest that excluding other greenhouse gases can result in underestimating emissions reductions by $64 \%$ [42].

Recent work suggests that of the options for reducing black carbon emissions, residential stove and fuel interventions offer the highest net benefits per cost [63]. While development of emission factors for black carbon, and an applicable conservative crediting approach, was noted by market actors interviewed as providing a potential real benefit for capturing this emissions source from projects, progress has been limited by the sitespecific nature and the complexity of black carbon compared with other emission sources [64].

\section{Conclusion}

Carbon offset markets can provide a valuable means to support the further dissemination of improved cookstoves in developing countries. Offset markets can bring new sources of private-sector finance into projects and help to establish standards for monitoring and accountability, two recognized needs for cookstove projects. In addition, the methodologies developed for offset projects can also be used for Nationally Appropriate Mitigation Actions (NAMAs) and other forms of carbon finance; in particular those that involve payment for performance in reducing GHG emissions, to further expand implementation.

Nevertheless, this review suggests there remains 
considerable room for improvement in how offset methodologies account for the climate benefits of improved cookstoves. Our review of lessons learned and conversations with market actors and researchers has identified the following needs and potential directions for future research:

- Require accounting of uncertainty in estimates of emission reductions: Prior work has documented that uncertainty in the estimates of fuel usage, emission factors and fraction of non-renewable biomass $\left(f_{N R B}\right)$ can be large [34], yet current methodologies do not require accounting for uncertainty. This could be addressed in methodologies by requiring that the IPCC recommendations for uncertainty from the Good Practice Guidance and Uncertainty Management in National GHG Inventories be applied to project emission reductions calculations.

- Develop additional default factors for biomass consumption from baseline stoves: Currently the Clean Development Mechanism (CDM) methodology does not provide adequate default baseline fuelwood consumption values. Development of additional default factors could reduce uncertainty and further standardize estimates of baseline emissions. However, in 2012, a CDM technical working group found the variability in existing data estimates made development of default values unfeasible. Further work will depend on the availability of new research to address existing data gaps.

- Track the application, and review the integrity, of the new CDM default factors for $f_{N R B}$ : As discussed above, there is reason to believe that the current default factors, which imply that over $80 \%$ of all biomass use is non-renewable in the large majority of countries assessed, could overstate the fraction of non-renewable biomass in some project circumstances. Application of community and sub-national modelling assessments should be encouraged to validate and improve upon these values.

- Refine approaches to incorporate the use of data loggers in project monitoring: while it is generally assumed that new stoves replace old stoves for all cooking needs, observations suggest that this is not the case. Monitoring under the CDM currently requires that traditional stoves either be disposed of or continue to be monitored to determine ongoing usage. Ongoing monitoring of traditional stove use presents a challenge. Some have proposed using data loggers, to measure real fuel usage in households and gauge the new stoves' impact. However, further refinement is needed on how best to incorporate data loggers into monitoring plans and quantification of emission reductions in methodologies.

- Revisit the use of fossil fuel $\mathrm{CO}_{2}$ emission factors as surrogates for biomass combustion: under the CDM methodology, $\mathrm{CO}_{2}$ emissions factors for cookstoves are based on fossil fuel emissions, justified as the "substitution fuels likely to be used by similar users" [25]. This approach is largely a result of the constraints of the Marrakesh Accords that non-afforestation project activities cannot get credit for any increase in carbon stocks; however it remains an unsatisfactory workaround. This approach may result in a large undercrediting of cookstove projects and deserves further evaluation and review.

- Consider non- $\mathrm{CO}_{2}$ greenhouse gas emissions: Under the CDM methodologies, methane and nitrous oxide emissions are not considered, as they are under the Gold Standard methodology. Omission of these gases may not only result in under-crediting of cookstove projects, limiting their implementation, but could also lead to incorrect judgements about the relative benefits of different stoves [42]. Despite challenges in estimation methods for these gases, further research is needed to consider conservative ways to incorporate these emissions into current methodologies.

- Develop approaches to incorporate black carbon: Black carbon can make up a large portion of the climate impact of cookstove use, and yet it is not currently considered by carbon market methodologies. The sitespecific and complex nature of black carbon emissions' impact complicates their inclusion; new approaches will be needed that may differ radically from those currently used in project-based carbon accounting. The Climate and Clean Air Coalition, in which many countries and organizations participate, could provide a forum through which to pursue new methods.

\section{Acknowledgements and Disclaimer}

This study was made possible through financial support from the Swedish International Development Cooperation Agency (Sida). However, Sida was not involved in the design of the study and does not necessarily support the views expressed here, which are strictly the authors'.

We thank the market actors and technical experts we interviewed for sharing their valuable insights on lessons learned from implementing and evaluating improved cookstove projects. In particular, we thank the following individuals for providing their input: Robert Bailis (Associate Professor, Yale University), Neil Bellefeuille (Chief Executive Officer, The Paradigm Project), Simone Brant (Program Manager, Berkeley Air), Kai Carter (Impact Carbon), Gajanana Hedge and Julieta Nikova (Sustainable Development Mechanisms Methodologies Team, UNFCCC Secretariat), David Pennise (Technical Director, Berkeley Air), Dean Still (Executive Director, Aprovecho Research Center), Jimmy Tran (Director of Project Development, Impact Carbon), and Erik Wurster (CEO, UpEnergy). 


\section{References}

1. IEA. World Energy Outlook 2012. Paris, France: International Energy Agency; 2012. Available from: http://www.worldenergyoutlook.org (Accessed on 24 August 2013).

2. WHO. Indoor air pollution and health. Geneva, Switzerland: World Health Organization; 2011. Fact Sheet No. 292. Available from: http://www.who.int/ mediacentre/factsheets/fs292/en/index.html (Accessed on 24 August 2013).

3. Müller N, Spalding-Fecher R, Bryan S, Battye W, Kollmuss A, Sutter C, Tison S, Yamba F, Strom A, Hayashi D, Michelowa A, Marr M. Piloting greater use of standardised approaches in the Clean Development Mechanism-Phase I: Identification of countries and project types amenable to standardised approaches. Zurich, Switzerland: Perspectives Climate Change; 2011. Commissioned by the UK Department for International Development. Available from: http:// www.perspectives.cc/typo3home/groups/15/DFID/Pilo ting_greater_use_of_standardised_approaches_in_the _CDM_Phase_1_report.pdf (Accessed on 24 August 2013).

4. Burridge S, Goetz J, Heikel E, Higgins C, Kalanick C, Kastler J, Kedzuf C, Peterson D, Pikovsky A, Shepherd N, Cox P. Analysis of Cookstove ChangeOut Projects Seeking Carbon Credits. Minneapolis, MN, USA: Environmental Sustainability Clinic of the University of Minnesota Law School; 2011. Available from: http://papers.ssrn.com/sol3/papers.cfm?abstract_ id=1839765 (Accessed on 24 August 2013).

5. United Nations Foundations. Global Alliance for Clean Cookstoves; 2012. Available from: http://www. cleancookstoves.org/ (Accessed on 24 August 2013).

6. World Bank. Household Cookstoves, Environment, Health and Climate Change: A New Look at an Old Problem. Washington, D.C., USA; 2011. Available from: http://climatechange.worldbank.org/sites/ default/files/documents/Household\%20Cookstoves-web. pdf (Accessed on 24 August 2013).

7. Hayashi D, Michelowa A, Dransfeld B, Niemann M, Marr MA, Müller $N$, Wehner $S$, Krey $M$, Neufeld $C S$, Oppermann K. PoA Blueprint Book: Guidebook for PoA coordinators under CDM/JI 2. Revised Edition, Frankfurt, Germany: KfW Bankengruppe; 2010. Available from: https://www.kfw-entwicklungsbank.de/migration/ Entwicklungsbank-Startseite/Entwicklungsfinanzierung/ Umwelt-und-Klima/Klima\%C2\%ADschutzfonds/PDFDokumente-Klimaschutzfonds/PoA_BlueprintBook_ 08_02_2011.pdf (Accessed on 24 August 2013).

8. Johnson M, Edwards R, Ghilardi A, Berrueta V, Gillen D, Frenk CA, Masera O. Quantification of Carbon Savings from Improved Biomass Cookstove Projects. Environmental Science \& Technology. 2009;43 (7):2456-2462.

9. Cosbey A, Murphy D, Drexhage J, Balint J.
Realizing the Development Dividend: Making the CDM Work for Developing Countries. Winnipeg, Canada: International Institute for Sustainable Development; October 2006. Available from: http://www.iisd.org/pub lications/pub.aspx?id=694 (Accessed on 24 August 2013).

10. Sirohi S. CDM: Is it a "win-win" strategy for rural poverty alleviation in India? Climatic Change. 2007;84 (1):91-110.

11. Sutter C, Perreno JC. Does the current Clean Development Mechanism (CDM) deliver its sustainable development claim? An analysis of officially registered CDM projects. Climatic Change. 2007;84(1):75-90.

12. Olsen KH, Fenhann J. Sustainable development benefits of clean development mechanism projects: $A$ new methodology for sustainability assessment based on text analysis of the project design documents submitted for validation. Energy Policy. 2008;36(8):2819-2830.

13. Nussbaumer P. On the contribution of labelled Certified Emission Reductions to sustainable development: A multi-criteria evaluation of CDM projects. Energy Policy. 2009;37(1):91-101.

14. Alexeew J, Bergset L, Meyer K, Petersen J, Schneider L, Unger C. An analysis of the relationship between the additionality of CDM projects and their contribution to sustainable development. International Environmental Agreements: Politics, Law and Economics. 2010;10(3):233-248.

15. Disch D. A comparative analysis of the "development dividend" of Clean Development Mechanism projects in six host countries. Climate and Development. 2010;2(1):50-64.

16. Lee C, Lazarus M. Bioenergy Projects and Sustainable Development: Which Project Types Offer the Greatest Benefits? Climate and Development. 2013; $0(0): 1-13$.

17. European Parliament. Directive 2009/29/EC of the European Parliament and of the Council of 23 April 2009. L 140/63. Strasbourg, France: 2009. Available from:http://eurlex.europa.eu/LexUriServ/LexUriServ. douri=OJ:L:2009:140:0063:0087:en:PDF (Accessed on 24 August 2013).

18. Schneider L. Crediting the displacement of nonrenewable biomass under the CDM. Freiburg, Germany: Oko-Institut; 2007.

19. The Gold Standard. Technologies and Practices to Displace Decentralized Thermal Energy Consumption. Geneva, Switzerland: November 2011. Available from: http://www.cdmgoldstandard.org/wp-content/uploads/ 2011/10/GS_110411_TPDDTEC_Methodology.pdf (Accessed on 24 August 2013).

20. UNEP Risoe Centre. UNEP Risoe CDM/JI Pipeline Analysis and Database, 1 July 2012. Available from: http://cdmpipeline.org/ (Accessed on 24 August 2013).

21. The Gold Standard. The Gold Standard Project Registry. 2012 Available from: http://www.cdmgoldstandard.org/our-projects/project-registry (Accessed 
on 24 August 2013).

22. Verified Carbon Standard. The VCS Project Database. Washington, DC, USA: Verified Carbon Standard; 2012. Available from: http://www.vcs projectdatabase.org/ (Accessed on 10 September 2013).

23. Arnold JEM, Köhlin G, Persson R. Woodfuels, livelihoods, and policy interventions: Changing Perspectives. World Development. 2006;34(3):596-611.

24. Baker \& McKenzie. What is a Programme of Activities? CDM Rulebook: Clean Development Mechanism Rules, Practice \& Procedures. Available from: http://www.cdmrulebook.org/452 (Accessed on 24 August 2013).

25. UNFCCC. AMS II.G.: Energy efficiency measures in thermal applications of non-renewable biomass. Bonn, Germany: United Nations Framework Convention on Climate Change, Executive Board of the Clean Development Mechanism; 2012. Available from: http://cdm.unfccc.int/methodologies/DB/REQC2MYZJJ6I 7BC9SKCS32T2K87AOW (Accessed on 10 September 2013).

26. American Carbon Registry. Switch from nonrenewable biomass for thermal applications by the user. Arlington, VA, USA: American Carbon Registry, April 2011. Available from: http://americancarbon registry.org/carbon-accounting/carbon-accounting/ switch-from-non-renewable-biomass-for-thermalapplications-by-the-user (Accessed on 24 August 2013).

27. UNFCCC. Tool for the demonstration and assessment of additionality (Version 05.2.1). Bonn, Germany: United Nations Framework Convention on Climate Change, Executive Board of the Clean Development Mechanism; 2008. 39th Meeting Report, Annex 10. Available from: http://cdm.unfccc.int/ methodologies/PAmethodologies/tools/am-tool-01-v5. 2.pdf/history_view (Assessed on 24 August 2013).

28. UNFCCC. Guidelines on the demonstration of additionality of small-scale project activities. Bonn, Germany: United Nations Framework Convention on Climate Change, Executive Board of the Clean Development Mechanism; 2012. Version 09.0, 68th Meeting Report, Annex 27. Available from: https://cdm. unfccc.int/Reference/Guidclarif/meth/methSSC_guid05 .pdf (Accessed on 24 August 2013).

29. UNFCCC. Efficient Fuel Wood Stoves for Nigeria. United Nations Framework Convention on Climate Change, Executive Board of the Clean Development Mechanism; 2009. CDM Project Design Document Form, Version 2.1, 06-August-2009, completed by atmosfair $\mathrm{gGmbH}$ and $\mathrm{LHL}$ e.Vbia. Available from: http://cdm.unfccc.int/Projects/DB/RWTUV12456 85309.5/view (Assessed on 24 August 2013).

30. UNFCCC. "Turbococinas", rural cooking stove substitution program in El Salvador Version 4. United Nations Framework Convention on Climate Change, Executive Board of the Clean Development Mechanism; 2011. Clean Development Mechanisms Small-
Scale Programme of Activities Design Document Form (CDM-SSC-PoA-DD) Version 01. Available from: http://cdm.unfccc.int/ProgrammeOfActivities/poa_db/ 1MVROYJLH50F26N39US7DBI8CQGEZ/view (Accessed on 24 August 2013).

31. UNFCCC. CDM Lusaka Sustainable Energy Project 1. United Nations Framework Convention on Climate Change, Executive Board of the Clean Development Mechanism; 2009. CDM Project Design Document Form, Final Version 2.0, 28 July 2009, submitted by Zambia. Available from: https://cdm. unfccc.int/Projects/DB/TUEVSUED1252930846.25/ view (Accessed on 24 August 2013).

32. UNFCCC. Rwanda Natural Energy Project: Water Treatment Systems for Rural Rwanda (Mugonero Esepan, Rwesero, Nyagasambu), United Nations Framework Convention on Climate Change, Executive Board of the Clean Development Mechanism; 2011. Clean Development Mechanisms SmallScale Programme of Activities Design Document Form (CDM-SSC-PoA-DD) Version 03. Available from: http://cdm.unfccc.int/Projects/DB/RWTUV130545317. 2/view (Accessed on 24 August 2013).

33. UNFCCC. Biogas Support Program-Nepal Activity-4, United Nations Framework Convention on Climate Change, Executive Board of the Clean Development Mechanism; 2011. CDM Project Design Document Form Version 03: 22 December 2006. Available from: https://cdm.unfccc.int/Projects/DB/ TUEV-SUED1252930846.25/view (Accessed on 24 August 2013).

34. Johnson $M$, Edwards $R$, Masera O. Improved stove programs need robust methods to estimate carbon offsets. Climatic Change. 2010;102(3-4):641-649.

35. Bailis R. Controlled Cooking Test (CCT). London, UK: Household Energy and Health Programme, Shell Foundation; 2004. Available from: http://www.pciaonline.org/files/CCT_Version_2.0_0.pdf (Accessed on 24 August 2013).

36. Bailis R, Ogle D, MacCarty N, Still D. The Water Boiling Test (WBT). London, UK: Household Energy and Heath Programme, Shell Foundation; 2007. Available from: http://pciaonline.org/files/WBT_Version_ 3.0_0.pdf (Accessed on 24 August 2013).

37. Bailis $R$, Smith KR, Edwards $R$. Kitchen Performance Test (KPT). CLondon, UK: Household Energy and Health Programme, Shell Foundation; 2007. Available from: http://pciaonline.org/files/ KPT_Version_3.0_0.pdf (Accessed on 24 August 2013).

38. UNFCCC. AMS-I.E.: Switch from non-renewable biomass for thermal applications by the user. Bonn, Germany: United Nations Framework Convention on Climate Change, Executive Board of the Clean Development Mechanism; July 2012. Valid from 3 August 2012 onwards. Available from: http://cdm. unfccc.int/methodologies/DB/WHTQUFLWCVNB9CIUZ 
C198A712WGQR4 (Accessed on 10 September 2013).

39. Aprovecho Research Center. Overview of Standard Stove Testing. Kanagawa, OR, USA: Aprovecho Research Center; 2009. Available from: http://www.aprovecho.org/lab/index.phpoption=com_ru bberdoc\&view $=$ doc\&id=4\&format=raw (Accessed on 24 August 2013).

40. Johnson M, Edwards R, Ghilardi A, Berrueta V, Masera $\mathrm{O}$. Why current assessment methods may lead to significant underestimation of GHG reductions of improved stoves. Boiling Point. 2007;54:11-4.

41. Abeliotis K, Pakula C. Reducing health impacts of biomass burning for cooking-The need for cookstove performance testing. Energy Efficiency. 2013; 6(3):585-594.

42. Johnson M, Edwards R, Frenk CA, Masera O. In-field greenhouse gas emissions from cookstoves in rural Mexican households. Atmospheric Environment. 2008;42(6):1206-1222.

43. Berrueta $V$, Edwards R, Masera O. Energy performance of wood-burning cookstoves in Michoacan, Mexico. Renewable Energy. 2008;33(5):859-870.

44. UNFCCC. Thirty-ninth meeting of the SmallScale Working Group. Bonn, Germany: United Nations Framework Convention on Climate Change, Clean Development Mechanism; 2012. Version 01.1. Available from: http://cdm.unfccc.int/Panels/ssc_wg/meetings/ 039/meetrep.pdf (Accessed on 24 August 2013).

45. IPCC National Greenhouse Gas Inventories Programme. IPCC Good Practice Guidance and Uncertainty Management in National Greenhouse Gas Inventories. Penman J, Kruger D, Galbally I, Hiraishi T, Nyenzi B, Emmanul S, Buendia L, Hoppaus R, Martinsen T, Meijer J, Miwa K, Tanabe K, editors. Kanagawa, Japan: Institute for Global Environmental Strategies; 2000. Available from: http://www.ipcc-nggip.Iges. or.jp/public/gp/english/ (Accessed on 24 August 2013).

46. UNFCCC. Definition of renewable biomass. Bonn, Germany: United Nations Framework Convention on Climate Change, Executive Board of the Clean Development Mechanism; February 2006. 23rd Meeting Report, Annex 18. Available from: http://cdm. unfccc.int/EB/023/eb23_repan18.pdf (Accessed on 24 August 2013).

47. UNFCCC. Call for public inputs in relation to standardized approaches for facilitating the baseline emission calculations under AMS-I.E Switch from nonrenewable biomass for thermal applications and AMSII.G Energy efficiency measures in thermal applications of non-renewable biomass-SSC CDM methodologies for displacement of non-renewable biomass. Bonn, Germany: United Nations Framework Convention on Climate Change, Clean Development Mechanism, Small-Scale Working Group; 2011. 33rd Meeting Report, Annex 8. Available from: http://cdm.unfccc.int/Panels/ssc_wg/ meetings/033/ssc_033_an08.pdf (Accessed on 10 September 2013).
48. Reddy RC. The World Bank-Inputs on the "standardized approaches for baseline emission calculations under SSC CDM methodologies for displacement of non-renewable biomass". 2011. Available from: http://cdm.unfccc.int/public_inputs/2011/ eb63_03/index.html (Accessed on 24 August 2013).

49. Ghilardi A, Guerrero G, Masera O. Spatial analysis of residential fuelwood supply and demand patterns in Mexico using the WISDOM approach. Biomass and Bioenergy. 2007;31(7):475-491.

50. Zerzawy F, Wagner B, Kitzinger X. Atmosfair gGmbH: Submission in response to "Call for public inputs in relation to standardized approaches for facilitating the baseline emission calculations under AMS I.E and AMS II.G for displacement of non-renewable biomass". 2011. Available from: http://cdm.unfccc.int/public_inputs/ 2011/eb63_03/index.html (Accessed on 24 August 2013).

51. Matsuo N. Climate Experts, Ltd.-Submission in response to "Call for inputs on standardized baselines in SSC methodologies for displacing non renewable biomass". 2011. Available from: http://cdm.unfccc.int/ public_inputs/2011/eb63_03/index.html (Accessed on 24 August 2013).

52. UNFCCC. Default Values of Fraction of NonRenewable Biomass for Least Developed Countries and Small Island Developing States. Bonn, Germany: United Nations Framework Convention on Climate Change, Executive Board of the Clean Development Mechanism; 2012 May. 67th Meeting Report, Annex 22. Available from: http://cdm.unfccc.int/DNA/fNRB/index.html (Accessed on 24 August 2013).

53. Dewees PA. The woodfuel crisis reconsidered: Observations on the dynamics of abundance and scarcity. World Development. 1989;17(8):1159-1172.

54. Geist HJ, Lambin EF. Proximate Causes and Underlying Driving Forces of Tropical Deforestation. BioScience. 2002;52(2):143.

55. Blunck M, Griebenow C, Rammelt M, Zimm C. Carbon Markets for Improved Cooking Stoves: A GIZ guide for project operators. Revised edition-January 2011. Eschborn, Germany: GIZ-HERA; 2011. Available from: $\quad$ http://www.giz.de/Themen/en/dokumente/giz 2011-en-carbon-markets-for-improved-stoves.pdf

(Accessed on 24 August 2013).

56. IPCC/OECD/IEA. Revised 1996 IPCC Guidelines for National Greenhouse Gas Inventories. Houghton JT, Meira Filho LG, Lim B, Treanton K, Mamaty I, Bonduki Y, Griggs DJ, Callender BA, editors. Bracknell, UK: UK Meteorological Office; 1996. Available from: http://www.ipccnggip.iges.or.jp/public/gl/invs1.html (Accessed on 24 August 2013).

57. Anenberg SC, Balakrishnan $\mathrm{K}$, Jetter J, Masera O, Mehta S, Moss J, Ramanathan V. Cleaner Cooking Solutions to Achieve Health, Climate, and Economic Cobenefits. Environmental Science \& Technology. 2013;47(9):3944-3952. 
58. Berkeley Air. Berkeley Air Monitoring Group. 2012. Available from: http://www.berkeleyair.com/ (Accessed on 24 August 2013).

59. UNEP, WMO. Integrated Assessment of Black Carbon and Tropospheric Ozone: Summary for Decision Makers. Bonn, Germany: United Nations Environment Programme and World Meteorological Organization; June 2011. Available from: http://www.unep.org/ dewa/Portals/67/pdf/BlackCarbon_SDM.pdf (Accessed on 24 August 2013).

60. Rehman $I H$, Ahmed $T$, Praveen PS, Kar A, Ramanathan V. Black carbon emissions from biomass and fossil fuels in rural India. Atmospheric Chemistry and Physics Discussions. 2011;11(4):10845-10874.

61. Feng $Y$, Ramanathan $V$, Kotamarthi VR. Brown carbon: A significant atmospheric absorber of solar radiation? Atmospheric Chemistry and Physics Discussions. 2013;13(1):2795-2833.

62. Grieshop AP, Marshall JD, Kandlikar M. Health and climate benefits of cookstove replacement options. Energy Policy. 2011(12):7530-7542.

63. International Resources Group. Black Carbon Emissions in Asia: Sources, Impacts, and Abatement Opportunities. Chantilly, Virginia, USA: U.S. Agency for International Development (USAID); 2010. Available from: http://www.pciaonline.org/files/Black\%20Carbon \%20Emissions\%20in\%20Asia.pdf (Accessed on 10 September 2013).

64. Ramanathan V, Carmichael G. Global and regional climate changes due to black carbon. Nature Geoscience. 2008;1(4):221-227. 
Appendix 1. List of Acronyms

\begin{tabular}{|c|c|}
\hline ACR & American Carbon Registry \\
\hline$B_{y}$ & biomass fuel consumption \\
\hline ССТ & Controlled Cooking Test \\
\hline CDM & Clean Development Mechanism \\
\hline CDM SSC WG & CDM Small-Scale Working Group \\
\hline CERs & Certified Emission Reductions \\
\hline $\mathrm{CH}_{4}$ & methane \\
\hline CMP & Conference of the Parties (to the Kyoto Protocol) \\
\hline $\mathrm{CO}$ & carbon monoxide \\
\hline $\mathrm{CO}_{2} \mathrm{e}$ & carbon dioxide equivalent \\
\hline$E F_{\text {proj_fossilfuel }}$ & emission factors for fuel combustion \\
\hline EU ETS & European Union Emissions Trading System \\
\hline $\begin{array}{l}f_{N R B} \\
\text { GHGs }\end{array}$ & $\begin{array}{l}\text { fraction of non-renewable biomass } \\
\text { greenhouse gases }\end{array}$ \\
\hline GS & Gold Standard \\
\hline $\mathrm{Gt} \mathrm{CO}_{2}$ & gigaton of carbon dioxide \\
\hline IPCC & Intergovernmental Panel on Climate Change \\
\hline KPT & Kitchen Performance Test \\
\hline LDCs & Least Developed Countries \\
\hline MAI & mean annual increment \\
\hline NAMAs & Nationally Appropriate Mitigation Actions \\
\hline NCV & net calorific value \\
\hline $\mathrm{N}_{2} \mathrm{O}$ & nitrous oxide \\
\hline PDDs & project design documents \\
\hline PM & particulate matter \\
\hline PoAs & Program of Activities \\
\hline SIDS & Small Island Developing States \\
\hline UNFCCC & United Nations Framework Convention on Climate Change \\
\hline VCS & Verified Carbon Standard \\
\hline VERs & Verified Emission Reductions \\
\hline WBT & Water Boiling Test \\
\hline WISDOM & Woodfuel Integrated Supply/Demand Overview Mapping \\
\hline
\end{tabular}

